\title{
Marketing in sport leagues: optimising the product design. Intra-championship competitive intensity in French football Ligue 1 and basketball Pro $A$
}

\author{
Nicolas Scelles* \\ UFR STAPS, Campus II, \\ Université de Caen Basse-Normandie, \\ 2 boulevard du Maréchal Juin, 14032 Caen Cedex, France \\ E-mail: nicolasscelles@hotmail.com \\ *Corresponding author
}

\section{Michel Desbordes}

\author{
UFR STAPS, \\ Université Paris Sud 11, \\ 15, rue Georges Clémenceau, 91405 Orsay, France \\ E-mail: michel.desbordes@u-psud.fr
}

\section{Christophe Durand}

\author{
UFR STAPS, Campus II, \\ Université de Caen Basse-Normandie, \\ 2 boulevard du Maréchal Juin, 14032 Caen Cedex, France \\ E-mail: christophe.durand@unicaen.fr
}

\begin{abstract}
This article deals with the optimisation of the sport leagues product thanks to adequate rules. It features a new model called intra-championship competitive intensity which measures outcome uncertainty and reversals in the standings of a sport league. The model depends on the league product design and, in particular, on the number of sports stakes in the standings. Intra-championship competitive intensity was calculated in French football Ligue 1 (league without playoffs) and basketball Pro $A$ (league with playoffs) over the period 2004-2009. The results show that Pro A intra-championship competitive intensity surpassed Ligue l's, whereas the latter benefits from a better competitive balance. Then, we propose a product design which maximises intra-championship competitive intensity and marketing and sponsoring efficiency in the European context. This design needs specific marketing actions to be optimised.
\end{abstract}

Keywords: intra-championship competitive intensity; ICCI; outcome uncertainty; product design; sports stakes; French professional leagues; football; basketball; competitive balance; $\mathrm{CB}$; sport management and marketing; playoffs.

Reference to this paper should be made as follows: Scelles, N., Desbordes, M. and Durand, C. (2011) 'Marketing in sport leagues: optimising the product design. Intra-championship competitive intensity in French football Ligue 1 and basketball Pro A', Int. J. Sport Management and Marketing, Vol. 9, Nos. 1/2, pp.13-28. 
Biographical notes: Nicolas Scelles is a Doctor in Sciences and Techniques of Physical and Sports Activities (STAPS) of the University of Caen Basse-Normandie and contractual in the Unit of Teaching and Research (UFR) STAPS of the University of Paris Sud 11. His area of specialisation is professional sports political economics. His thesis carries on competitive intensity which is landed through two levels: intra-match and intra-championship. The problem of his work consists in wondering about rules which allow optimising competitive intensity of professional sports leagues and the feasibility of their setting up considering leagues and clubs officials perception.

Michel Desbordes is a Doctor in Management Sciences, a Professor in the UFR STAPS of the University of Paris Sud 11, Co-director of the research centre of Sports, Politique et Transformations Sociales (SPOTS) and the Director of ISC Paris in sports marketing and management. His area of specialisation is sports marketing and in particular marketing of sports services: management of sports events and functional organisation of the events, sports sponsoring, sports federations and the influence of their governance on the management (political dimension), sociological approach of the sports consumer and link between sport and the management of the activities.

Christophe Durand is a Doctor in Management Sciences and Professor in the UFR STAPS of the University of Caen Basse-Normandie. His area of specialisation is professional sports political economics: professional sports leagues regulation, relations between professional sport and public sphere, physical and sports activities factor of socio-economic development, ethics in governance and marketing strategy of sports organisations. He leads a double approach - economic and political - in the perspective of a comparative initiative according to three axes: temporal, spatial and inter-sports. He is a member of the marketing commission of the French professional league of basket-ball (Ligue Nationale de Basket).

\section{Introduction}

In 1960, McCarthy reduced the marketing mix concept to four elements: product, price, place and promotion. These four elements were called the 4 P's. Fifty years after, in spite of various developments in marketing, the 4 P's continue to inspire marketing teachings, professionals and researches (Armstrong et al., 2009; Armstrong and Schultz, 1992; Kotler and Armstrong, 2010; Kotler et al., 2004). Sport marketing does not break the rule [a fifth $\mathrm{P}$ is sometimes added with public relations (Mullin et al., 2007)]. In this paper about marketing in sport leagues, we focus the attention on one of the 4 P's: the product. This one is complex. Mullin et al. (p.149) note that "the sport product is both an integrated ensemble and a bunch of components with lives on their own" (Figure 1). We concentrate on the core of the sport product which explains its particularities. Indeed, Mullin et al. (pp.149-150) add that "it is the 'playing out' of rules/techniques, equipment, and venue that makes sport products distinct from all other products". Besides, several researchers highlight that live sports action and general atmosphere are key attraction factors because they allow spectators to express eustress and stimulation derived from the match (Macpherson et al., 2000; Madrigal, 1995; Mahony and Howard, 1998; Wann, 1995). 
This paper deals with the effect of sports rules about leagues product appeal. In relation to this aspect, Mullin et al. (p.152) write: "One might argue that changes in rules and techniques are comparable to design changes in any consumer product." It is necessary to agree on the definition of design in marketing. It constitutes "all the elements which affect the aspect and the functioning of the product from the point of view of the consumer" [Kotler et al., (2004), p.345]. Sports rules integrate this type of elements. Moreover the notion of design is used by authors to qualify the optimal structure of sporting contests (Scarf and Bilbao, 2006; Szymanski, 2003). In the same logic, our idea is to highlight sports rules which contribute to optimise the quality of the matches and championships. This quality depends on key success factors: absolute and relative quality of the teams and importance of the matches.

Figure 1 Core elements of the sport product and a sample of extensions)

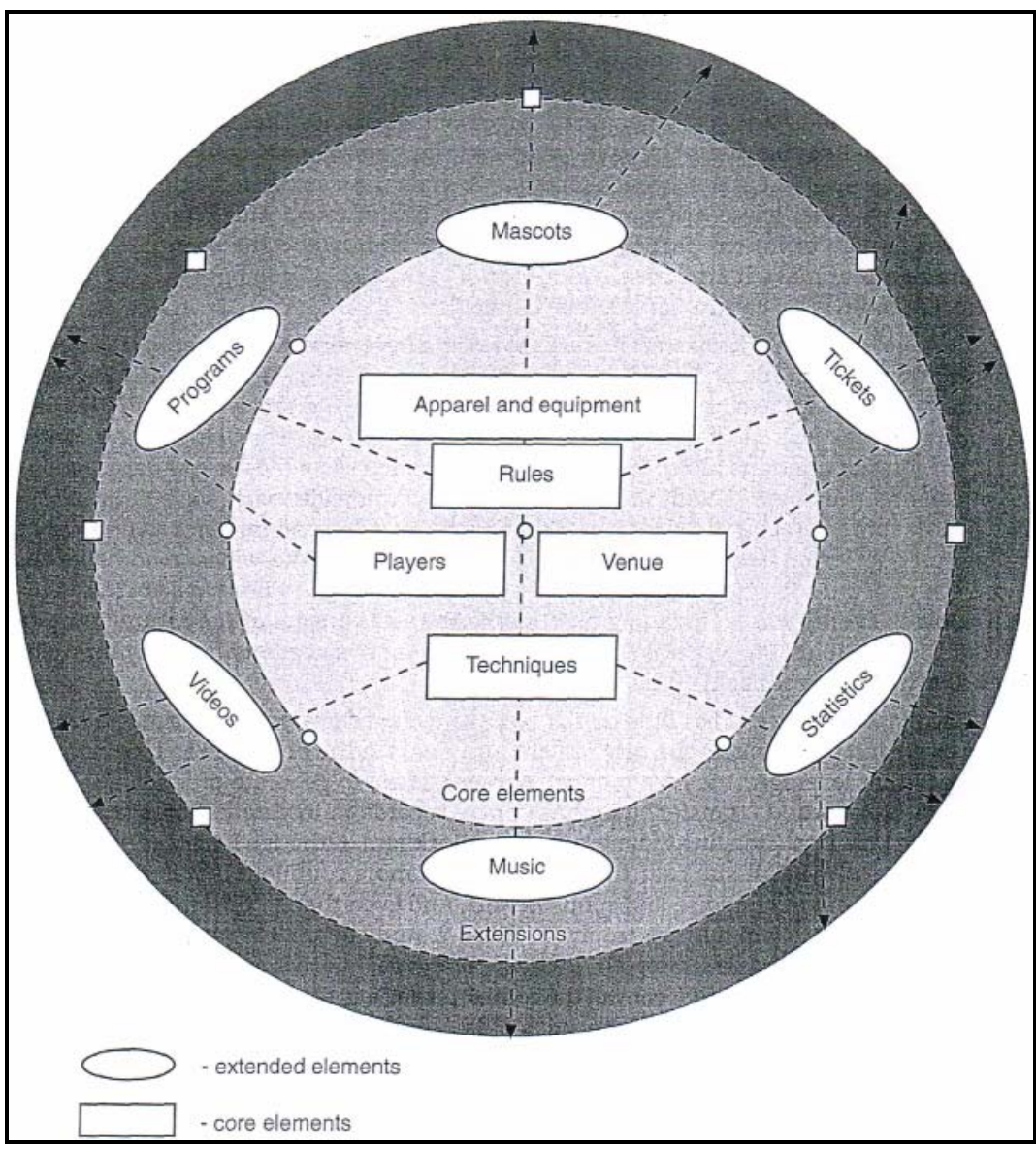

Source: Mullin et al. (2007, p.150)

The relative quality of the teams is inherent to the concept of competitive balance (CB). In professional sports economics, $\mathrm{CB}$ is currently well documented (Andreff, 2008; Groot, 2008; Humphreys, 2002; Késenne, 2000; Kringstad and Gerrard, 2004, 2005, 2007; Michie and Oughton, 2004; Neale, 1964; Rottenberg, 1956; Szymanski, 2003; 
Zimbalist, 2002). It postulates the necessity of equilibrium of the teams in a league to guarantee outcome uncertainty and thus generate public demand. Nevertheless, CB is insufficient to attract audience. Even if it is balanced and uncertain, a match will be less interesting - less important - if the teams have no prize to defend. Sport leagues product must incorporate stakes which ensue from the sports rules of the competition. Sports stakes are not analysed in the literature (Andreff, 2008). The first authors that undertook research on this topic were Kringstad and Gerrard (2004, 2005). They conceptualised competitive intensity (CI) as a factor integrating outcome uncertainty and sports stakes. We add reversals to improve this concept of CI (Scelles, 2009, 2010; Scelles and Durand, 2007, 2010a, 2010b). Therefore, we consider CI to be a function of three key factors:

1 sports stakes felt by consumers

2 uncertainty degree

3 reversals.

In this paper, CI will be considered at the intra-championship (IC) level [as opposed to the intra-match (IM) level] to measure the quality of sport leagues product design. The grounds of study are French football Ligue 1 and basketball Pro A over the period 20042009. The structure of the article is eight-fold. In the second part, we present the contextual setting of the two precedent leagues. In the third part, we operate a literature survey about CI. In the fourth part, we clarify the methodology to measure ICCI. In the fifth part, we compare some factors which theoretically explain ICCI for Ligue 1 and Pro $A$ and develop our hypotheses. In the sixth part on the results, we evaluate the ICCI of Ligue 1 and Pro A over the period 2004-2009 and test our hypotheses. In the seventh part, we envisage a discussion about CI, efficiency and marketing in European sport leagues.

\section{Contextual setting}

French football Ligue 1 and basketball Pro $A$ are two leagues that have evolved very differently over the past 20 years. At the beginning of the $1990 \mathrm{~s}$, they were the two most economically developed French leagues, even though Ligue 1 had already an advantage over Pro A. Ligue 1 benefits from the French football World Cup 1998 to increase attendances and audiences and so revenues. By contrast, Pro $A$ suffers from national competition with football and rugby. The latter became professional in 1995 and since then, good management and marketing choices have enabled Top 14 (French rugby first division) to outdistance Pro A. Besides, Pro $A$ lies more and more in the USA National Basketball Association (NBA)'s shadow. These factors partially explain the economic differences with Ligue 1 (Table 1).

Pro $A$ suffers from the bad development of its league (Ligue Nationale de Basket, LNB) between 1987 and 2003 too. René Le Goff, President of LNB since 2003 until its death in 2010, that we interviewed during our doctoral research (Scelles, 2009, 2010), gave three reasons:

1 the lack of confidence of the Fédération Française de Basket-Ball (FFBB) which negotiates TV rights itself, what does not allow LNB to manage both TV and marketing rights. Besides, according to R. Le Goff, FFBB is a federation which 
makes a bad promotion of its sport, except for the best French players who are in NBA! It represents a supplementary difficulty for LNR.

2 The wish of the best clubs to keep their power so as to continue to benefit from a competitive advantage. These clubs have frozen the system.

3 An insufficient administrative structure until 2003 (only four employees!) which was deliberately maintained at a weak level to allow FFBB and the best clubs to keep their power.

During his presidency, R. Le Goff tried to correct these difficulties and encouraged the clubs to develop new revenues instead of relying too strongly on public subsidies. However, the initial backwardness in comparison with LFP and Ligue Nationale de Rugby (LNR) has continued to increase.

Table 1 Presentation of French football Ligue 1 and basketball Pro $A^{1}$

\begin{tabular}{|c|c|c|}
\hline & Ligue 1 & $\operatorname{Pro} A$ \\
\hline $\begin{array}{l}\text { Name of the league which } \\
\text { organise the competition }\end{array}$ & $\begin{array}{c}\text { Ligue de Football } \\
\text { Professionnel } \\
\text { (LFP, Ligue Nationale de } \\
\text { Football or LNF until 2002) }\end{array}$ & $\begin{array}{l}\text { Ligue Nationale de Basket } \\
\text { (LNB) }\end{array}$ \\
\hline Beginning of the league & 1944 & 1987 \\
\hline $\begin{array}{l}\text { Number of employees of the } \\
\text { league }\end{array}$ & $\approx 60$ & 12 \\
\hline $\begin{array}{l}\text { Beginning of the } \\
\text { competition }\end{array}$ & 1932 & 1921 \\
\hline Number of teams & 20 & 16 \\
\hline Championship system & Only a regular season & Regular season + playoffs \\
\hline Most crowned team & Saint-Étienne (ten) & ASVEL Lyon-Villeurbanne (17) \\
\hline Last crowned team (2010) & Marseille & Cholet \\
\hline $\begin{array}{l}\text { Average revenues without } \\
\text { players' sales }\end{array}$ & $52.3 \mathrm{M} €$ & $3.8 \mathrm{M} €$ \\
\hline Part of TV rights & $55 \%$ & $2 \%$ \\
\hline Part of sponsoring & $18 \%$ & $48 \%$ \\
\hline Part of match revenues & $14 \%$ & $16 \%$ \\
\hline Part of merchandising & $11 \%$ & $3 \%$ \\
\hline Part of public subsidies & $2 \%$ & $31 \%$ \\
\hline
\end{tabular}

Note: ${ }^{1}$ Season $2008-2009$ for the financial data

\section{Literature survey about CI}

The notion of CI was proposed by Kringstad and Gerrard (2004, 2005). According to them, apart from the degree of equality of teams' playing strengths (or CB), audiences are also interested in the prizes that may be distributed within the framework of the league [Kringstad and Gerrard, (2007), p.27]. Consequently, CI relates to stakes of European selection, relegation to inferior divisions, etc. [Cavagnac and Gouguet, (2006), p.11]. Kringstad and Gerrard (2007) select two different indicators as leagues are North 
American (closed) or European (opened with promotions and relegations). For the USA leagues, Kringstad and Gerrard use classically the Herfindahl index to analyse the distribution of the participants in playoffs. The Herfindahl index represents the sum of the squares of the parts of presences in playoffs of every team. The sum of the parts of presences is equal to one. For the five major European leagues of football, Kringstad and Gerrard choose the rate of relegation of the teams recently promoted.

Kringstad and Gerrard rely on original measures with regard to those pre-existent by privileging the access to key places: qualified for playoffs or relegation. Nevertheless, a limit which can be mentioned is that the analysis concerns several seasons considered each as a homogeneous group synthesised by the final standings. They do not thus allow to inform about the progress of the championships game week after game week. However, it is possible that from the principle of Kringstad and Gerrard CI, it can be proposed measures getting at once outcome uncertainty and the sports stakes in a dynamic perspective during a season. Besides, we think that reversals must be incorporated, for they are vectors of the league standing effect proposed by Neale (1964, p.3) in a classical article:
"there is excitement in the daily changes in the standings or the daily changes in possibilities of changes in standings. The closer the standings, and within any range of standings the more frequently the standings change, the larger will be the gate receipts."

Therefore, we consider CI to be a function of three key factors (Scelles, 2009, 2010; Scelles and Durand, 2007, 2010a, 2010b):

1 stakes felt by consumers

2 degree of uncertainty

3 reversals.

It is necessary to have perceived stakes, close AND evolving scores and standings. Uncertainty and reversals are connected with sports stakes (without stakes, we consider there are not uncertainty and reversals). Consequently, in CI model, only uncertainty and reversals are calculated but they integrate sports stakes. Moreover CI may be measured at two scales: intra-match (IMCI) and intra-championship (ICCI). This is the second which is analysed in the next section.

\section{Methodology for ICCI measures}

At IC level, outcome uncertainty and reversals respectively correspond to:

- the percentage of teams with possibility of fast states fluctuation in the standings (IC uncertainty, ICU)

- the average of the fluctuations in states in the standings, which is calculated by game week in order to compare championships not presenting the same number of game weeks (IC fluctuations, ICF).

The notion of state in the standings must be understood as a potential status for a club connected to its rank (champion, qualified for a continental competition or for playoffs when it applies, simply maintained in the division, relegated). It corresponds to the 
different sports stakes at the standings. Contrary to ICU, ICF do not need numerous precisions to explain their calculation. It is just necessary to think that there are not fluctuations during the first game week because there are not standings previously. Consequently, the formula to calculate ICF is the following one:

$$
\begin{aligned}
I C F= & \text { Number of fluctuations in states in the standings during the entire } \\
& \text { championship / (Number of game weeks }-1)
\end{aligned}
$$

ICU is the percentage of teams with possibility of fast fluctuation in state in the standings. We could calculate this percentage for each game week, then the average. Nevertheless, in the first game weeks, as there are no spreads, it is not relevant to calculate the percentage of teams with possibility of fast fluctuation in state in the standings: all teams are concerned. Moreover stakes are stronger towards the end of the championship. It also may sensible to give more value for last game weeks. Consequently, we propose an indicator which follows two conditions:

1 limiting the number of calculated percentages and, in particular, not retaining the ones of the first game weeks;

2 calculating the percentages of the last game weeks.

Eight moments have been saved: at the third of the championship, at half, at the two thirds, at five game weeks of the end of the championship and the ones of the following game weeks.

Besides, it turns out necessary to precisely distinguish the situations where there is ICU from the ones where there is none. If reducing it at the next game week is too restrictive considering the number of game weeks of a championship during a regular season, it can be relevant to limit it to the two next game weeks whatever the type of competitions. For example, in French football Ligue 1, we can acknowledge there is ICU when the gap between the team(s) which hold(s) the $\operatorname{rank}(\mathrm{s})$ to reach or avoid and the one(s) ranked respectively at the ranks directly below or above does not exceed six points (two wins). Consequently, ICU corresponds to the following calculation:

\section{$I C U=$ Mean of the percentage of teams with possibility of fluctuation of state in the standings during the two next game weeks at the eight saved months}

Lastly, we believe there is a hierarchy between ICU and ICF, and that ICU is of prime importance, trumping that of ICF since we regard maintaining uncertainty for as long as possible is more important than reversals (Figure 2). To justify this hierarchy, we can envisage two situations:

- the first corresponds to a championship with few fluctuations but an uncertainty which is maintained until the end

- the second coincides with a championship rich in fluctuations in his first part but without uncertainty is his second part.

The first situation seems better to guarantee the public interest during the entire championship. 
Figure 2 ICCI model

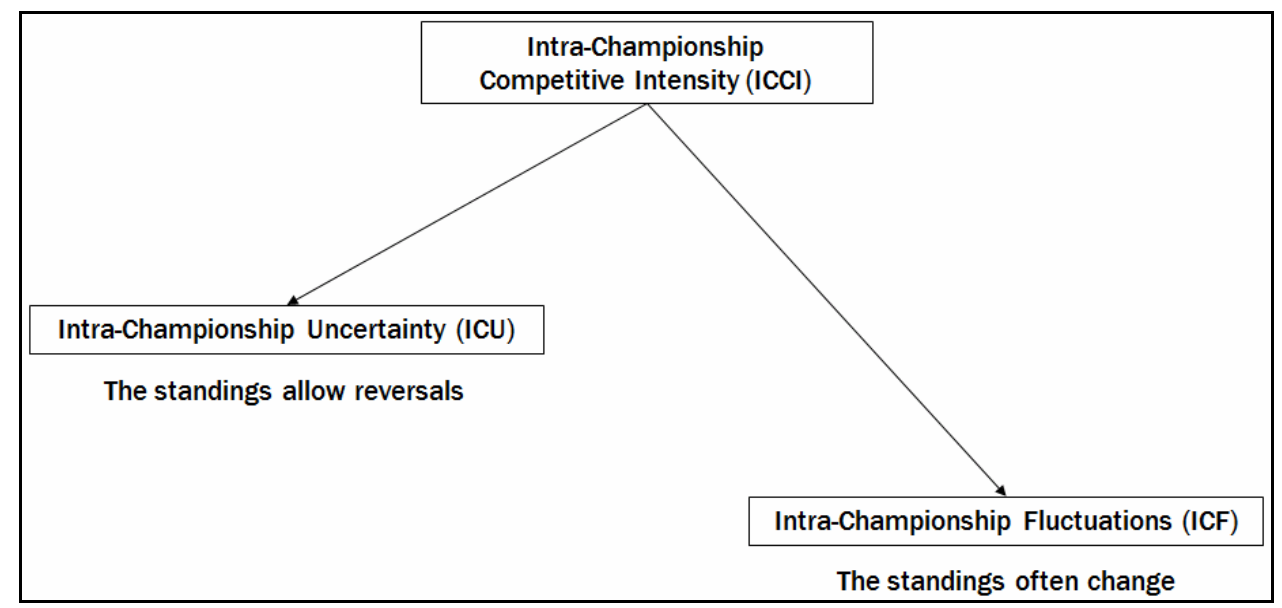

\section{Explanatory factors of ICCI and hypotheses}

In a theoretical point of view, ICCI will be all the stronger since:

- the number of sports stakes are large

- the percentage of ranks which allow to remain in the division is weak (if it is too high, there is a strong risk that teams have no stake to defend)

- the number of game weeks is weak (it reduces the potentiality that the gaps are widening at the standings)

- $\quad$ B is good.

CB data are given, that are NSCB (Noll-Scully measure of CB; Noll, 1988; Scully, 1989) and SDPP or standard deviation of the percentage of points or victories (SDPV). NSCB consists of connecting the effective measure of the standard deviation of the percentage of the season's wins with its theoretical value, which is representative of a perfectly balanced championship, while taking into account the number of matches. To calculate this theoretical value, the formula is $\sigma(w)=0,5 / \sqrt{ } m$, with $\sigma$ the standard deviation, $w$ the percentage of victories and $m$ the number of matches by team [Fort and Quirk, (1995), p.1267]. The interpretation of the ratio between effective and theoretical values is the following: the competition is all the stronger when the ratio is next to zero; on the opposite side, the less uncertain the competition, the stronger the ratio is. Though NSCB is often used in the literature, we think it disadvantages excessively leagues where teams play a large number of matches because of a formulation which depends on a totally unrealistic theoretical situation (perfect balance between teams). It justifies that we complete it by SDPP or SDPV even though this one presents the opposite weakness, that is to say a tendency to diminish with the number of matches. The explanation of the mention of NSCB and SDPP or SDPV is due to the will to know if the ICCI differences between competitions are generated by differences in terms of $\mathrm{CB}$ or by distinct formats. 
Number of teams and sports stakes of Ligue 1 and Pro $A$ are given over the period 2004-2009 (Table 2). They allow to highlight data which can explain ICCI (Table 3). In relation to the Table 3, for a same level of CB, we can suppose that Pro $A$ benefits from a better ICCI than Ligue 1 because of a larger number of sports stakes, a weaker percentage of ranks which allow to remain in the division and a weaker number of game weeks. We can consider that Pro $A$ have more sports stakes because the five last game weeks count for $62.5 \%$ in ICU (they are five of the eight saved moments). Consequently, in Pro A, in average, they are 10.4 sports stakes in 2004-2005 and 2005-2006 then 7.5 sports stakes in 2006-2007, 2007-2008 and 2008-2009.

Table 2 Number of teams and sports stakes in French football Ligue 1 and basketball Pro A over the period 2004-2009

\begin{tabular}{|c|c|}
\hline Ligue 1 & $\operatorname{Pro} A$ \\
\hline 20 teams: & 18 teams (16 in 2007-2008 and 2008-2009): \\
\hline $\begin{array}{l}1 \text { st champion and qualified in } \\
\text { Union of European Football } \\
\text { Associations (UEFA) Champions } \\
\text { League without preliminary round }\end{array}$ & $\begin{array}{l}\text { 1st and } 2 \text { nd qualified in playoffs with two matches } \\
\text { at home out of three in quarter- and eventually } \\
\text { semi-finals (the final is on neutral field) }\end{array}$ \\
\hline $\begin{array}{l}\text { 2nd qualified in UEFA Champions } \\
\text { League without preliminary round }\end{array}$ & $\begin{array}{l}\text { 3rd and } 4 \text { th qualified in playoffs with two matches } \\
\text { at home out of three in quarter-finals }\end{array}$ \\
\hline $\begin{array}{l}\text { 3rd qualified for the preliminary } \\
\text { round of UEFA Champions League }\end{array}$ & $\begin{array}{l}\text { From } 5 \text { th to } 8 \text { th qualified in the preliminary round } \\
\text { of playoffs with two matches at home out of three in } \\
\text { the preliminary round of playoffs in } 2004-2005 \text { and } \\
2005-2006 \text { then simply qualified in playoffs }\end{array}$ \\
\hline 4th qualified in UEFA Cup & $\begin{array}{l}\text { From } 9 \text { th to } 12 \text { th qualified in the preliminary round } \\
\text { of playoffs in 2004-2005 and 2005-2006 then } \\
\text { simply maintained in the division }\end{array}$ \\
\hline 5th qualified in Intertoto Cup & 13th and 14th maintained in the division \\
\hline $\begin{array}{l}\text { From } 6 \text { th to } 17 \text { th, maintained in the } \\
\text { division }\end{array}$ & $\begin{array}{l}\text { 15th maintained in the division in } 2004-2005 \text {, } \\
2005-2006 \text { and } 2006-2007 \text { then relegated }\end{array}$ \\
\hline \multirow[t]{2}{*}{ 18th, 19th and 20th relegated } & $\begin{array}{l}\text { 16th maintained in the division in 2004-2005 and } \\
2005-2006 \text { then relegated }\end{array}$ \\
\hline & $\begin{array}{l}17 \text { th and } 18 \text { th relegated in } 2004-2005,2005-2006 \\
\text { and 2006-2007 }\end{array}$ \\
\hline
\end{tabular}

Table 3 Data which can explain French football Ligue 1 and basketball Pro A ICCI over the period 2004-2009

\begin{tabular}{lccc}
\hline Competitions & $\begin{array}{c}\text { Number of game } \\
\text { weeks }\end{array}$ & $\begin{array}{c}\text { Number of sports } \\
\text { stakes }\end{array}$ & $\begin{array}{c}\text { Percentage of ranks which allow } \\
\text { to remain in the division }\end{array}$ \\
\hline $\begin{array}{l}\text { Ligue } 1 \\
\text { Pro } A^{1}\end{array}$ & 38 & 7 & From $50 \%$ to $60 \%$ \\
& 34 & $\begin{array}{c}\text { Six until five game } \\
\text { weeks of the end }\end{array}$ & $22 \%$ \\
& $\begin{array}{c}\text { 13 from the end of the } \\
\text { 29th game week }\end{array}$ \\
\hline
\end{tabular}

Notes: ${ }^{1}$ In 2007-2008 and 2008-2009, 30 game weeks. In 2006-2007, 2007-2008 and 2008-2009, five sports stakes until five game weeks of the end then nine sports stakes from the end of the 25th game week (29th game week in 2006-2007. In $2006-2007,39 \%$ of ranks which allow to remain in the division. In 2007-2008 and 2008-2009, 37.5\% of ranks which allow to remain in the division. 
The precedent elements lead to the following hypotheses:

H1 Pro $A$ has a better ICCI than Ligue 1.

H2 Ligue 1 can increase its potential of ICCI with a better product design.

\section{Results}

Table 4 refers to data relative to $\mathrm{CB}$ and ICCI of Ligue 1 and Pro A. It is clear that Ligue 1 is more balanced than Pro $A$ (better NSCB and SDPP). The solidarity among football clubs (partially egalitarian distribution of TV revenues) may explain the homogeneity of Ligue 1. The results are different about ICCI. Indeed, Ligue 1 suffers from the absence of playoffs in terms of ICU whereas Pro $A$ profits from a large number of teams which are qualified in playoffs. Consequently, Pro A has a better ICCI than Ligue 1 (validation of H1). ICCI measures are interesting because they feature different perspective of the appeal of leagues from the one of CB. They show that an appropriate format of competition can compensate for a perfectible CB. On the contrary, the positive effect of a good CB can be reduced by a perfectible design of the sport leagues product. This is the case for Ligue 1. How this one can increase its potential of ICCI?

Table 4 French football Ligue 1 and basketball Pro A CB and ICCI over the period 2004-2009

\begin{tabular}{|c|c|c|c|c|c|}
\hline \multirow{2}{*}{ Competitions } & \multirow{2}{*}{ Seasons } & \multicolumn{2}{|c|}{$C B^{1}$} & \multicolumn{2}{|c|}{$I C C I^{2}$} \\
\hline & & $N S C B^{3}$ & $S D P P^{4}$ & $I C U^{5}$ & $I C F^{6}$ \\
\hline \multirow[t]{6}{*}{ Ligue 1} & $2004-2005$ & 1.10 & $8.8 \%$ & $85.6 \%$ & 3.35 \\
\hline & $2005-2006$ & 1.44 & $11.6 \%$ & $59.4 \%$ & 3.97 \\
\hline & 2006-2007 & 1.06 & $9.0 \%$ & $75.0 \%$ & 4.54 \\
\hline & $2007-2008$ & 1.36 & $11.0 \%$ & $88.1 \%$ & 4.22 \\
\hline & $2008-2009$ & 1.56 & $12.6 \%$ & $71.9 \%$ & 3.70 \\
\hline & Average & 1.30 & $10.6 \%$ & $76.0 \%$ & 3.96 \\
\hline \multirow[t]{6}{*}{$\operatorname{Pro} A$} & 2004-2005 & 1.95 & $16.7 \%$ & $94.4 \%$ & 5.09 \\
\hline & $2005-2006$ & 1.95 & $16.8 \%$ & $87.5 \%$ & 5.58 \\
\hline & 2006-2007 & 1.86 & $16.0 \%$ & $86.8 \%$ & 3.85 \\
\hline & $2007-2008$ & 1.66 & $14.2 \%$ & $85.2 \%$ & 2.52 \\
\hline & $2008-2009$ & 1.54 & $13.2 \%$ & $75.0 \%$ & 4.17 \\
\hline & Average & 1.79 & $15.4 \%$ & $85.8 \%$ & 4.29 \\
\hline
\end{tabular}

Notes: ${ }^{1}$ Competitive balance; ${ }^{2}$ intra-championship competitive intensity;

${ }^{3}$ Noll-Scully measure of competitive balance; ${ }^{4}$ standard deviation of percentage of points; ${ }^{5}$ intra-championship uncertainty; ${ }^{6}$ intra-championship fluctuations.

The first remark is that the number of sports stakes of Ligue 1 can be improved and the percentage of ranks which allow to remain in the division can be diminished. A decrease in the number of teams would reduce the percentage of ranks which allow to remain in the division but teams would likely reject this option. The organisation of playoffs and 
playdowns may contribute to an ICCI increase but it brings about a surplus of matches to play in an already charged calendar. To reduce the number of matches without diminishing the number of teams, the constitution of geographic groups inspired by the model of North American leagues could be interesting. However, one can think that a unique group is a factor of greater understanding of the product for the clients. Perhaps a better idea consists of removing the League Cup. This one began to attribute a qualifying place in UEFA Cup when it was decided to reduce Ligue 1 from 20 to 18 teams (period 1997-2002). But Ligue 1 came back to 20 clubs in 2002. Removing the League Cup therefore does not seem unjustified. The interest is that it makes it possible to have dates to organise playoffs and playdowns. These ones could be very short if each round consists of a single match. The home team would be the best team. Consequently, there would be an incentive to be classified to a rank rather than another one. Thus, it encourages sports stakes and ICCI.

Our proposition is to save 20 teams (Table 5). The first eight are qualified for the playoffs with an incentive to be ranked at the best place. The teams ranked from 16 to 19 participate in playdowns and the 20th is relegated. Playoffs and playdowns are simply understandable for the clients because they involve respectively eight and four clubs, namely all teams, as soon as they begin. Interviews of French leagues organisers show that relegations restrain clubs' investments, in particular by sponsors. Indeed, clubs cannot secure their presence in first division each season, contrary to the USA teams which play in closed leagues. We therefore limit relegation to only one plus eventually one: the last loser in playdowns play versus the winner of playoffs in second division to know which take part in Ligue 1 the next season (the champion of second division is directly promoted). Ideal design of Ligue 1 product finally benefits from nine sports stakes (and even 13 in the five last game weeks) and limits the percentage of ranks which allow to remain in the division to $35 \%$.

Table 5 The ideal design of French football Ligue 1 product

\begin{tabular}{|c|c|}
\hline Ranks & Sports stakes \\
\hline 1 & $\begin{array}{c}\text { At home in quarter finals and in case of semi-finals and qualified in UEFA } \\
\text { Champions League }\end{array}$ \\
\hline 2 & At home in quarter finals and in case of semi-finals \\
\hline $3-4$ & At home in quarter finals \\
\hline $5 / 8$ & Qualified in playoffs \\
\hline $9 / 15$ & Remain in the division \\
\hline $16-17$ & At home in first round of playdowns \\
\hline 18 & At home in case of match vs. 19 in playdowns \\
\hline 19 & Away \\
\hline 20 & Relegated \\
\hline
\end{tabular}

We may think that this product design is not optimal because we can still reduce the percentage of ranks which allow to remain in the division. Nevertheless, such a reduction does not respect some constraints:

- Increasing the number of teams concerned by playdowns is not compatible with the necessity to diminish the risk of relegation so as to encourage clubs' investments. 
- If 12 teams take part in playoffs, they are not simply understandable for the clients because all the teams do not participate in the first round. Moreover it is sportily unfair since teams in the second part of the standings are qualified for the playoffs. If ten teams take part in playoffs, sport merit is respected but the problem of understanding for the clients remains.

The respect of these constraints explains why we consider that the product design proposed in the precedent paragraph is optimal. Finally, Ligue 1 can increase its potential of ICCI with a better product design (validation of $\mathrm{H} 2$ ). More generally, we can think that all European sport leagues can increase its potential of ICCI in being inspired by the product design envisaged for Ligue 1. Generalising to the USA sport leagues is more difficult because of the impossibility to organise playdowns (no relegation).

\section{Discussion: CI, efficiency and marketing of European sport leagues}

Results show that Ligue 1 has an inferior ICCI than Pro $A$ and can improve it in proposing a better product design. Nevertheless, it is not sufficient to attract the consumers: in spite of a good ICCI, Pro A does not succeed in expanding. In fact, it is necessary to be conscious that ICCI and more generally CI is only one factor of success among others. Besides, CI needs marketing actions in order to optimise its effect: for example, a good promotion in the good places (TV, internet, specialised newspapers...). However, CI can give some new perspectives in the reflection about the maximisation of the efficiency of sport leagues, in particular in Europe where leagues are characterised by qualification in continental competitions and promotions/relegations. These sports stakes do not exist in the USA sport leagues, which are limiting the possibility of optimising CI. It justifies that the discussion concerns rather European sport leagues. It deals with two points: the role of $\mathrm{CI}$ in the optimisation of the European sport leagues efficiency and the effect of marketing actions on CI.

\section{What is an efficient sport league within the European context?}

The efficiency of a sport league and more generally of major professional sport teams is the subject of numerous researches (Barros et al., 2008; Barros and Douvis, 2009; Barros and Leach, 2006; O'Reilly and Nadeau, 2006). Within the European context, leagues face a dilemma: encouraging both $\mathrm{CB}$ and their clubs' competitiveness in European competitions. Studies about the possibility of conciliating the two aspects show they are contradictory (Andreff and Bourg, 2006; Jardin, 2009). Has the introduction of CI in the analysis changed this reasoning? In other words, can we conciliate $\mathrm{CI}$ and the competitiveness of national clubs in European competitions? The philosophy of the measure of $\mathrm{CI}$ is to enable each club to have a sports stake to defend. Such an incentive can exist even though $\mathrm{CB}$ is perfectible. The product design previously mentioned must therefore guarantee $\mathrm{CI}$, including in an unbalanced competition. What matters is that at least two teams are close in the standings for two different sports stakes and not all the teams. In these conditions, leagues' organisers can favour teams qualified in European competitions.

Currently, Ligue 1 tries to encourage CB and the competitiveness of its teams in European competitions, whereas the literature seems to indicate that a choice must be 
made between the two elements. At the same time, the Ligue 1 product design is not optimal towards CI. A more efficient decision could be to make the choice of the competitiveness of its teams in European competitions and to introduce a product design inspired by the one previously proposed. The choice of the competitiveness in European competitions suggests a less egalitarian distribution of TV revenues among teams in order to favour the best teams. Besides, additional investments in clubs likely results from the reduction of the risk of relegation. In a context where the organisation of Euro 2016 by France can lead to an improvement of French stadiums and thus an increase in marketing and sponsoring revenues, the choice of the previous decision might be decisive for French clubs football. However, at least two threats complicate its enforcement: the disapproval of clubs not qualified in European competitions and of the ones of Ligue 2, and the historical absence of playoffs and playdowns in football (even though the Dutch Eredivisie and the Belgian Jupiler League have adopted such a formula). The marketing and sponsoring efficiency of the sport league must therefore cope with a few constraints.

\section{What are the marketing actions which make it possible to credit optimal CI?}

During the SportelMonaco 2009, Eurodata TV Worldwide Vice President Jacques Braun explained TV success of sport in these terms:

"Federations as well as organisers of sports entertainment draw their ideas of renewal of the sport from the universe of the fiction by adding of suspense and by dramatising their events to make them more attractive." [Pierre, (2009), p.35].

If optimisation of CI must generate maximal suspense, dramatisation needs specific marketing actions such as extra-sports 'spectacularisation'. It may be exemplified by French TV channel TF1 during rugby World Cup 2007. TF1 made of Sébastien Chabal a public icon by appropriate enactment and promotion. The advantage of sports entertainment for TV channels is its predictability. As Desbordes et al. (2004, p.183) put it, "the sports events, contrary to the current events or the news items, are predictable and the media can influence the progress. It predisposes them to play a role in trade rationalisations and explains their particular economic attraction". The economic interest of sports events is particularly true with regard to television programming. Moreover Desbordes et al. indicate that "sports events easily feature in the most profitable slots of the television programming". This fact allows TV channels to optimise the attraction of firms for advertising and establish specific marketing actions like trailers to maximise audience. These elements credit the optimisation of CI.

However, leagues must set up marketing actions as well. They must benefit from good CI to communicate about sports stakes of matches and even strengthen the importance the public perceives from these confrontations. An opportunity consists of taking advantage of the possibilities offered by the internet to attract fans by promotion on the leagues' official websites and the ones of other actors which are interested in the optimisation of spectacle (TV channels, websites specialised in sports, online bets...). Besides, clubs must put forward marketing actions. People which attend matches are essentially based in a local area. Moreover fans go to their clubs' website. They should thus set up a promotion focusing on the importance of sports stakes that makes it possible to reach the target by using every means improving a message visibility (official websites, billing in strategic places of the urban area, promotion in local newspapers...). 
Such actions would complete those of the leagues. Their combination would optimise the effects of the new product design.

\section{Conclusions}

The ICCI model differs from the $\mathrm{CB}$ in the view of the interest of competitions. It partially questions the importance of $\mathrm{CB}$ since quite unbalanced competitions can manage to have a good ICCI thanks to an appropriate format of competition. For example, French basketball Pro $A$ benefits from a better ICCI than football Ligue 1 in spite of a weaker CB. To optimise ICCI, the prevalence of having maximal sports stakes is put forward. A solution is to apply playoffs and playdowns. Hence, the optimal sport league product design sought to include them. The marketing and sponsoring efficiency of the sport league also requires aiming at the limitation of the risk of a relegation to attract more investors. Consequently, only one relegation plus eventually another should be saved. Nevertheless, the proposed changes need specific marketing actions to be optimised. These marketing actions must be set up by all the stakeholders of the professional sports system and, in particular, by leagues and clubs. Besides, the proposed modifications will not be easily accepted by all the actors, in particular in football. Dutch and Belgian leagues have introduced the movement for the organisation of playoffs and thus transforming their product design. Will another football league dare to follow this new tendency or even extend it?

\section{Acknowledgements}

We are indebted to Mickael Vaislic for his very useful help and to the reviewers for their excellent advices.

\section{References}

Andreff, W. (2008) 'Équilibre compétitif et contrainte budgétaire dans une ligue de sport professionnel: Vers une meilleure gouvernance du football français', La lettre de l'AFSE, Vol. 72, pp.1-26, available at http://www.afse.fr/lettres/Lettre-72.pdf, (accessed on 8 December 2008).

Andreff, W. and Bourg, J-F. (2006) 'Broadcasting rights and competition in European football', in Jeanrenaud, C. and Késenne, S. (Eds.): The Economics of Sport and the Media, pp.37-70, Edward Elgar, Cheltenham.

Armstrong, G., Kotler, P., Harker, M. and Brennan, R. (2009) Marketing: An introduction, Pearson Education Limited, Harlow, England.

Armstrong, J.S. and Schultz, R.L. (1992) 'Principles involving marketing policies: An empirical assessment', Marketing Letters, Vol. 4, No. 3, pp.253-265, available at $\mathrm{http}: / /$ repository.upenn.edu/cgi/viewcontent.cgi?article=1029\&context=marketing_papers, (accessed on 3 August 2010).

Barros, C.P. and Douvis, J. (2009) 'Comparative analysis of football efficiency among two small European countries: Portugal and Greece', International Journal of Sport Management and Marketing, Vol. 6, No. 2, pp.183-199.

Barros, C.P. and Leach, S. (2006). 'Analyzing the performance of the English F.A. Premier League with an econometric frontier model', Journal of Sports Economics, Vol. 7, No. 4, pp.391-407. 
Barros, C.P., del Corral, J. and Garcia-del-Barrio, P. (2008) 'Identification of segments of soccer clubs in the Spanish league first division with a latent class model', Journal of Sports Economics, Vol. 9, No. 5, pp.451-469.

Cavagnac, M. and Gouguet, J-J. (2006) 'Talent sportif et équilibre compétitif: Une approche par la théorie des jeux', Revue Juridique et Économique du Sport, No. 79, pp.7-31.

Desbordes, M., Ohl, F. and Tribou, G. (2004) Marketing du Sport, Economica, Paris.

Fort, R. and Quirk, J. (1995) 'Cross-subsidization, incentives, and outcomes in professional team sports leagues', Journal of Economic Literature, No. 33, pp.1265-1299.

Groot, L. (2008) Economics, Uncertainty and European Football: Trends in Competitive Balance, Edward Elgar, Cheltenham, UK/Northampton, MA.

Humphreys, B.R. (2002) 'Alternatives measures of competitive balance in sports leagues', Journal of Sports Economics, Vol. 3, No. 2, pp.133-148.

Jardin, M. (2009) 'Enhancing competitive balance versus winning the Champion's League (or the league's dilemma)', Paper presented at the First European Conference in Sports Economics, 14-15 September, Paris.

Késenne, S. (2000) 'Revenue sharing and competitive balance in professional team sports', Journal of Sports Economics, Vol. 1, No. 1, pp.56-65.

Kotler, P. and Armstrong, G. (2010) Principles of Marketing, Pearson Education, Upper Saddle River, NJ.

Kotler, P., Dubois, B. and Manceau, D. (2004) Marketing Management, Pearson Education France, Paris.

Kringstad, M. and Gerrard, B. (2004) 'The concepts of competitive balance and uncertainty of outcome', International Association of Sports Economists Conference Paper, 0412.

Kringstad, M. and Gerrard, B. (2005) 'Theory and evidence on competitive intensity in European soccer', International Association of Sports Economists Conference Paper, 0508.

Kringstad, M. and Gerrard, B. (2007) 'Competitive balance in a modern league structure', Communication abstract at the North American Society for Sport Management Conference, 30 May to 2 June, Ft. Lauderdale, Florida, available at http://www.nassm.com/files/conf_abstracts/2007_1715.pdf, (accessed on 12 June 2007).

Macpherson, T., Garland, R. and Haughey, K. (2000) 'Attracting fans to the game', Conference Proceedings of Australian and New Zealand Marketing Academy (ANZMAC), Gold Coast, Australia, available at http://smib.vuw.ac.nz:8081/www/ANZMAC2000/CDsite/papers/m/Macpher1.PDF (accessed on 18 January 2007).

Madrigal, R. (1995) 'Cognitive and affective determinants of fan satisfaction with sporting event attendance', Journal of Leisure Research, Vol. 27, No. 3, pp.205-227.

Mahony, D.F. and Howard, D.R. (1998) 'The impact of attitudes on the behavioural intentions of sport spectators', International Sports Journal, Vol. 2, No. 2, pp.96-110.

McCarthy, J.E. (1960) Basic Marketing: A Managerial Approach, Irwin, Homewood, IL.

Michie, J. and Oughton, C. (2004) Competitive Balance in Football: Trends and Effects, Research Paper, No. 2, Birkbeck, University of London, available at http://www.football-research.bbk.ac.uk/docs/competitivebalance.pdf, (accessed on 19 October 2005).

Mullin, B.J., Hardy, S. and Sutton, W.A. (2007) Sport Marketing, Human Kinetics, Champaign, IL.

Neale, W.C. (1964) 'The peculiar economics of professional sports: a contribution to the theory of the firm in sporting competition and in market competition', The Quarterly Journal of Economics, No. 78, Vol. 1, pp.1-14.

Noll, R.G. (1988) 'The economics of sports leagues', in Uberstine, G.A. (Ed.): Law of Professional and Amateur Sports, Clark Boardman, Deerfield, IL. 
O'Reilly, N.J. and Nadeau, J.P. (2006) 'Revenue generation in professional sport: a diagnostic analysis', International Journal of Sport Management and Marketing, Vol. 1, No. 4, pp.311-330.

Pierre, J. (2009). 'Les performances télévisées du sport à la loupe', Sport Stratégies, No. 200, pp.34-35.

Rottenberg, S. (1956) 'The baseball players' labor market', Journal of Political Economy, No. 64, Vol. 3, pp.242-258.

Scarf, P. and Bilbao, M. (2006) 'The optimal design of sporting contests', Paper No. 320/06, available at

http://www.mams.salford.ac.uk/mams/resources/uploads/File/working-papers/optimal\% 20design $\% 20$ of $\% 20$ sporting\%20 contests--working\%20paper\%20320-06.pdf (accessed on 18 June 2008).

Scelles, N. (2009) L'incertitude du résultat, facteur clé de succès du spectacle sportif professionnel, L'intensité compétitive des ligues: Entre impacts mesurés et effets perçus, STAPS (Sciences et Techniques des Activités Physiques et Sportives, Sciences and Technics of Physical and Sports Activities) PhD thesis, University of Caen Basse-Normandie, Caen, France.

Scelles, N. (2010) La glorieuse incertitude du sport: L'intensité compétitive des ligues professionnelles: Entre impacts mesurés et effets perçus, Éditions Universitaires Européennes, Sarrebruck, Deutschland.

Scelles, N. and Durand, C. (2007) 'L'impact du bonus sur l'intensité compétitive intra-match: Incidence réelle et potentielle dans les championnats français de rugby, de football et de basket', Revue Européenne de Management du Sport, No. 18, available at http://www.infosport.org or http://www.territorial.fr.

Scelles, N. and Durand, C. (2010a) 'Economic design: optimiser l'intensité compétitive sous contraintes, Le cas de la Coupe du Monde de la FIFA', Jurisport, No. 99, pp.42-45.

Scelles, N. and Durand, C. (2010b) 'Incertitude du résultat et demande du public: L'intensité compétitive intra-match comme variable clé. Le cas de la Ligue des champions de l'UEFA (1955/2008)', Science \& Motricité, DOI: 10.1051/sm/2009011, available at http://www.science-motricite.org.

Scully, G.W. (1989) 'The business of major league baseball', University of Chicago Press, Chicago.

Szymanski, S. (2003) 'The economic design of sporting contests', Journal of Economic Literature, Vol. 41, No. 4, pp.1137-1187, available at http://www.vanderbilt.edu/Econ/faculty/Vrooman/econdesign.pdf (accessed on 15 January 2006).

Wann, D.L. (1995). 'Preliminary validation of the sport fan motivation scale', Journal of Sport \& Social Issues, Vol. 19, No. 4, pp.377-396.

Zimbalist, A.S. (2002) 'Competitive balance in sports leagues: an introduction', Journal of Sports Economics, Vol. 3, No. 2, pp.111-121. 